\title{
水稻ごま葉枯病々 斑周縁組織の澱粉蓄積機構
}

3. 種々の化合物による人工病斑の形成ならびに澱粉分解作用の抑制*

\section{田中寬康・赤井重 恭**}

Hiroyasu Tanaka and Shigeyasu Aкаг: On the mechanism of starch accumulation in tissues surrounding spots in leaves of rice plants due to the attack of Cochliobolus miyabeanus.

3. The formation of artificial spots and the inhibition of starch decomposition in rice leaves by various chemical compounds.

水稻ごま葉枯病々斑風縁組織では, 多量の澱粉が蓄 積し, かつその部分で $\beta$-amylase の活性が低下寸る ことはすでに報告した ${ }^{1,5)}$ 。この澱粉蓄積の原因を澱 粉の分解作用抑制という問題に焦点を合わせて考えた 場合, $\beta$-amylase 活性の低下原因の追及が必要とな る。その原因の一つとして筆者らは病原菌から, ある いは侵入によつて生理異常を起こした水稻細胞から $\boldsymbol{\beta}$-amylase を直接あるいは問接に阻害する物質が生 産されるのでないかと考えた。本実験ではこのような 考えから出発して, 種々の化合物浴液による水稻葉上 での人工病斑の形成ならびに澱粉流転作用が阻止され る状態を観察し, これらの現象と水稻葉の $\beta$-amylase

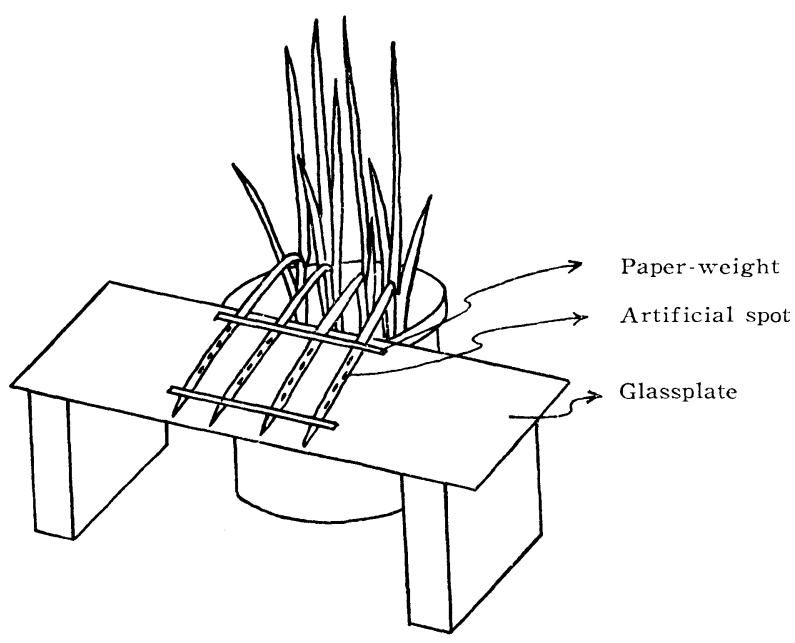

第 1 図水稻葉上への溶液の滴下法

Fig 1. Method of placing a drop of solution on rice leaves.

* 京都大学農学部植物病理学研究室業績, 第 130 号 水稻疾病の病態生理学的研究, 第 6 報

** 京都大学農学部植物病理学研究室
に対する前記化合物の直接あるいは間接的な阻害作用 との関係を調查して, 病斑㟃縁組織の澱粉異常蓄積の 原因と考えられる $\beta$-amylase 活性の低下現象を解明 しようとした。

\section{実験材料および実験方法}

供試水稻品種旭 4 号を既報1)のとおりに育成して, 草丈約 $50 \mathrm{~cm}$ になつたころ, 上位から第 2 葉を適宜 実験に供した。

人工病斑の形成ならびに澱粉流転作用の阻止 まず 水稻葉を第 1 図のよ5に切り離さずに台上に水平に固 定した。その葉面の適当な位置に，絸い毛筆でリノ一 100 倍液を小玫点（直径約 $2 \sim 3 \mathrm{~mm}$, 人 工病整を作万弓と思5大きさ）状に塗り， 直ちに汇紙で吸取つて，乾燥しないうちに 供試化合物の浚液をさきの細いスポイドで 滴下した。24時間後葉を切り取つて人工病 斑の形成状態を肉眼的に観察し,さらに既 報1)の才法にしたがつてアルコールで脱や した後，I-KI 溶液で染色して澱粉の残留 状態を観察したが，これを澱粉流転作用の 阻此力とした。

水稲葉の $\beta$-amylase に対する供試化合 物の阻害力 化合物の南接的な阻害作用を 知るために, 水稻葉の中央部を $2 g$ 科取し て, 直ちに長さ約 $1 \mathrm{~mm}$ に細切し, 乳鉢中 で硅砂と少量の純水とを加えて, $\mathrm{O}^{\circ} \mathrm{C}$ に冷 却しながら十分磨砕した。それに純水を加 え, ガーゼで沪過して $50 \mathrm{ml}$ としたもの を水稻葉 $\beta$-amylase の粗酵素液とした。 この粗酵素液 $5.0 \mathrm{ml}, \quad 0.4 \mathrm{M}$ 酢酸緩衝液（ $\mathrm{pH} \mathrm{6.0）}$ $2.0 \mathrm{ml}, 5 \%$ 可溶性洪粉溶液 $1.0 \mathrm{ml}$ および供試化合 物の溶液 $2.0 \mathrm{ml}$ を試験管に入れて十分混合し, $37^{\circ} \mathrm{C}$ 
の水槽中で 5 時間反応させ, この反応液 $2 \mathrm{ml}$ 中に生 成した還元糖をヂニトロサリチル酸法4)にしたがつて 定量し，その值を $\beta$-amylase の活性とした。化合物 の間接的な阻害作用を知るためには浸漬実験を行なつ た。水稻葉の中央部を $2 \mathrm{~g}$ 科取し, 約 $1 \mathrm{~cm}$ の長さに 切つて, $200 \mathrm{ml}$ 三肩フラスュ中で $100 \mathrm{ml}$ のリノ-100 倍液に暫時浸漬し, 十分水洗した後, 供試化合物溶液 $100 \mathrm{ml}$ 中に浸漬して, 室温に放置した。このとき水稲 葉は完全に溶液中に沈む。一定時間経過後，浸漬した 水稻葉片を取出して十分水洗し，前項と同じす法で粗 酵素液を調製した。B-amylase の活性の測定は, 供試 化合物溶液のかわりに純水 $2 m l$ を添加した以外はす ベて前項と同じ条件で行なつた。本実験では常に対照 区として同一時間純水に浸漬したものを用いた。

\section{実 験 結 果}

\section{I. 種々の化合物による人工病斑の形成ならびに澱 粉流転作用の阻止}

1. $\mathbf{H g C l}_{2}$ 上述したよ5に，本病々斑周縁組織で $\beta$-amylase の活性が低下する原因の一つとして，管 者らはその部分に $\beta$-amylase 活性を阻害する物質の 存在を考えた。もし存在するものとすれば，そのよう な物質を人工的に水稲葉に与字えた場合，その部分に $\beta$-amylase の活性低下がおこり，澱粉の蓄積を起す であろ5。筆者らはまず $\beta$-amylase に対して特に強 い阻害作用を有する $\mathrm{HgCl}_{2}$ を滴下して葉上に人工病 斑を作り，人工病斑内拈よびその㓮縁に打忛る澱粉の 異常分布を観察した。ただし $\mathrm{HgCl}_{2}$ は $\beta$-amylase 以 外の多くの酵素をも阻畫するものと考えられるので, 必ずしも最良の阻害物質ではないが, $\beta$-amylaseのみ を特異的に阻慧する物質が見当らないのでやむを得ず 使用した。

前述の方法にしたがい, 午後 5 時ごろに温室内の水 稻の葉上に 3 種類の濃度*)の $\mathrm{HgCl}_{2}$ 溶液を滴下した。 翌朝 9 時ごろには滴下部は浸潤状態を呈しているにす ぎないが，その後次第に細胞の壞死が進んで，24時間 後（午後 5 時ごろ）には周囲は黒褐色，中央部は灭色 の人工病玟:となり，凬緑部はやや黄化して中毒症状を 呈した（第 2 図，A）。しかして人工病斑には $\mathrm{HgCl}_{2}$ 溶液の濃度による質的な差は認められないが，病斑を 形成するまでの時間に多少の差が認められる。

*) $\mathrm{HgCl}_{2}$ は in vitro では $10^{-2} \mathrm{M}$ で完全に $\beta$ amylase を阻害するが, 葉面から吸収させた場合の細 胞内での稀釈等を考慮して, 滴下には $10^{-2}, 5 \times 10^{-2}$, $10^{-1} \mathrm{M}$ の 3 種類の濃度の溶液を用いた。
A

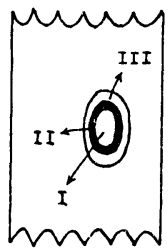

Artificlal

spot

$24 \mathrm{hrs}$. after dropping $\mathrm{HgCl} \mathrm{L}_{2}$ solutior. - Central part(grey), brown), III: Surrounding part (yellow), N : Iodostarch reaction (blue violet), V: Iodo-starch reaction (blue)

第 2 図 $\mathrm{HgCl}_{2}$ 溶液 $\left(10^{-2} \mathrm{M}\right)$ 滴下に上り形成 された人工病斑およびヨード澱粉反応を 示す模式図

Fig. 2. Schematic figures of the artificial spot and the starch distribution in rice leaves which were produced by dropping $\mathrm{HgCl}_{2}$ solution $\left(10^{-2} \mathrm{M}\right)$.

以上のような人工病斑ならびにその雕縁部における 澱粉の分布を観察するため，葉をアルコールに浸漬し て脱色後暗所に保つて I-KI 溶液に 24 時間以上浸清 した。ヨード澱粉反応は前述の病斑雕縁の黄化部を除 いたすべての部分でみられたが，病斑以外の健全部は 藍色であるにもかかわらず，病斑部は藍紫色であつ て，両者の色調は明瞭に区別することができた（第 2 図，B）。人工病斑部では細胞は壊死状態にあるから， 光合成作用すなわち澱粉合成作用は完全に抑えられて いるものと考えられるが，もし澱粉分解作用も完全に 抑えられているならば，その部分は健全部と同様に藍 色を呈するはずである。一方澱粉解作用にぜんぜん異 常がなければ，葉を 24 時間暗処理することによつて 澱粉が完全に消失する ${ }^{1)}$ のであるから，この部分は完 全に退色するはずである。したがつて人工病斑部に拈 いてヨード澱粉反応が藍紫色を呈したことは，この部 分において澱粉分解作用がかなり抑えられていること を示すものである。

一方人工病斑周縁の黃色部に沶いてヨード搌粉反応 がみられないのは，澱粉合成作用のみ抑えられて，分 解作用は抑制されていないことを意味する。この人工 病斑をごま葉枯病々斑と対比して, 壊死部一壊死部, 周 縁黄化部一中毒部々考えるならば，澱粉の分布異常と いう点に拈いては両者はかなり異なつている。しかし このことについては別の面から異なつたモデル実験を 行なつて補助するとして，ここでは $\beta$-amylase 阻害 剤を葉上に滴下して，その部分の澱粉分解作用を抑制 
第 1 表 呼吸系酵素阻害唷による水稲葉上の人工病斑の形成ならびに

その部分に怙ける澱粉流転作用の阻止

Tab. 1 The formation of artificial spots and the inhibition of starch translocation therein by various respiratory inhibitors on rice leaves.

\begin{tabular}{|c|c|c|c|c|c|c|c|c|c|c|}
\hline \multirow{3}{*}{$\begin{array}{l}\text { Respiratory } \\
\text { inhibitors }\end{array}$} & \multirow{3}{*}{$\begin{array}{l}\text { Conc. } \\
(\mathrm{M})\end{array}$} & \multicolumn{4}{|c|}{ Formation of artificial spots } & \multicolumn{5}{|c|}{ Inhibition of starch translocation } \\
\hline & & \multirow{2}{*}{$\begin{array}{l}\text { Degree of } \\
\text { formation }\end{array}$} & \multicolumn{3}{|c|}{ Color of spots } & \multirow{2}{*}{$\begin{array}{c}\text { Degree of } \\
\text { inhibition }\end{array}$} & \multicolumn{4}{|c|}{ Iodo-starch reaction } \\
\hline & & & $\mathrm{C}^{*}$ & $\mathrm{P}$ & $\mathrm{S}$ & & $\mathrm{C}$ & $\mathrm{P}$ & $\mathrm{S}$ & $\begin{array}{l}\text { Color } \\
\text { reaction }\end{array}$ \\
\hline $\begin{array}{l}\text { No dark- } \\
\text { treatment }\end{array}$ & - & - & & & & - & & & & $\mathrm{Bl}$ \\
\hline “Rino”*** & $1 \%$ & - & & & & - & & & & $\mathrm{Bl}$ \\
\hline Phloridzin & " & - & & & & - & & & & \\
\hline $\mathrm{NaF}$ & $"$ & - & & & & - & & & & \\
\hline $\mathrm{NaN}_{3}$ & " & - & & & & - & & & & \\
\hline $\boldsymbol{\alpha}, \boldsymbol{\alpha}^{\prime}$-dipyridyl & $"$ & - & & & & - & & & & \\
\hline o-phenanthrolin & $"$ & + & $(\mathrm{Br})^{* *}$ & & & - & & & & \\
\hline $\begin{array}{l}\text { 8-hydroxy- } \\
\text { quinolin }\end{array}$ & " & - & & & & - & & & & \\
\hline K-ethylxanthate & " & + & & $(\mathrm{Br})$ & & - & & & & \\
\hline Salicylaldoxime & " & - & & & & - & & & & \\
\hline $\begin{array}{r}\text { Na-diethyldithio- } \\
\text { carbamate }\end{array}$ & " & + & & $(\mathrm{Br})$ & $\mathrm{Y}$ & - & & & & \\
\hline $\begin{array}{l}\text { Monochloro- } \\
\text { acetic acid }\end{array}$ & $"$ & + & & $(\mathrm{Br})$ & $(\mathrm{Y})$ & + & + & & & $\mathrm{Bl} \cdot \mathrm{V}$ \\
\hline $\begin{array}{l}\text { Monoiodo- } \\
\text { acetic acid }\end{array}$ & " & +++ & $(\mathrm{G})$ & $\mathrm{Br}$ & $\mathrm{Y}$ & ++ & ++ & & & $\mathrm{Bl} \cdot \mathrm{V}$ \\
\hline $\begin{array}{l}\text { Monobromo- } \\
\text { acetic acid }\end{array}$ & " & ++ & & $(\mathrm{Br})$ & $(\mathrm{Y})$ & ++ & ++ & & ++ & $\mathrm{Bl} \cdot \mathrm{V}$ \\
\hline $\mathrm{KCN}$ & " & - & & & & - & & & & \\
\hline $\begin{array}{l}2,4- \\
\text { dinitrophenol }\end{array}$ & " & + & & $(\mathrm{Br})$ & & - & & & & \\
\hline
\end{tabular}

¿ C: central part, P: periphery, S: surrounding part.

** Bl: blue, Br: brown, G: grey, V: violet, $\mathrm{Y}$ : yellow; ( ) : slightly discolor.

*** From Nippon Noyaku Co.

することができることのみを強調したい。なお午後 5 時ごろに暗処理を開始した水稻葉上に前述と同様人工 病斑を形成させた場合には，病斑の肉眼的徵候にはあ まり差異がなかつたが，ヨード搌粉反応は，光合成作 用が行なわれないので，健全部には認められず，病斑 部の久無暗処理の場合と同様に藍紫色を呈した（第 2 図，C)。このことからも人工病斑部において搌粉の 酵素的分解がかなり阻止されているものと思われる。

2. その他の化合物 $\mathrm{HgCl}_{2}$ によつて水稲葉中の澱 粉流転作用がかなり阻止されたので, 呼吸采酵素阻害 剤 ${ }^{3}$, 金属塩類ならびにフェノール類などについても 同様な観察を行なつた（第 $1 ， 2$ および 3 表）。この 実験に供試した水稲はすべて処理時間（24 時間）中 暗所に保つた。

呼吸系酵素阻害剤の中には人工病斑を形成しないも
のも多数あつたが，供試したすべての重金属塩類なら びに phloroglucine を除いたフェノール類は人工病斑 を形成した。しかしこれらの化合物によつて形成さ れた人工病斑には，変色部分の範囲やその程度にかな りの差異があつたが，滴下物質の諸性質との間には明 瞭な関係を見出し得なかつた。なお形成された人工病 斑の中には，病斑部においてヨード澱粉反応を呈する ものと呈しないもの，すなわち澱粉流転作用を阻止す るものとしないものとが存在する。第 2 表において, $\mathrm{Ag}^{+}, \mathrm{Fe}^{+++}$病斑の中央部ならびに周囲, $\mathrm{Cu}^{++}, \mathrm{Hg}^{++}$ 病斑の周囲でョード澱粉反応が士であるのは，それら の部分が黒褐色に变色しているため，その判定が困難 であつたからである。 $\mathrm{Cu}^{++}, \mathrm{Fe}^{+++}$病斑の周縁部では ヨード澱粉反応はみられたが，人工病斑の周囲と周縁 部との間には細い環状の退色部（ヨード澱粉反応を呈 
第 2 表 重金属塩類 $\left(10^{-2} \mathrm{M}\right)$ による水稲葉上の人工病斑の形成ならびに その部分に打ける澱粉流転作用の阻止

Tab. 2. The formation of artificial spots and the inhibition of starch translocation therein by heavy metal solutions $\left(10^{-2} \mathrm{M}\right)$ on rice leaves.

\begin{tabular}{|c|c|c|c|c|c|c|c|c|c|c|}
\hline \multirow{3}{*}{$\begin{array}{l}\text { Metal } \\
\text { ions }\end{array}$} & \multirow{3}{*}{ Metal salts } & \multicolumn{4}{|c|}{ Formation of artrificial spots } & \multicolumn{5}{|c|}{ Inhibition of starch translocation } \\
\hline & & \multirow{2}{*}{$\begin{array}{l}\text { Degree of } \\
\text { formation }\end{array}$} & \multicolumn{3}{|c|}{ Color of spots } & \multirow{2}{*}{$\begin{array}{l}\text { Degree of } \\
\text { Inhibition }\end{array}$} & \multicolumn{4}{|c|}{ Iodo-starch reaction } \\
\hline & & & $\mathrm{C}^{*}$ & $\mathrm{P}$ & S & & $\mathrm{C}$ & $\mathrm{P}$ & $\mathrm{S}$ & $\begin{array}{l}\text { Color } \\
\text { reaction }\end{array}$ \\
\hline & $\begin{array}{l}\text { No } \\
\text { dark-treatment }\end{array}$ & - & & & & - & & & & $\mathrm{Bl}$ \\
\hline & “Rino" *** & - & & & & - & & & & $\mathrm{B} 1$ \\
\hline $\mathrm{Ag}^{+}$ & $\mathrm{AgNO}_{3}$ & +++ & B. $V^{* *}$ & B. $\mathrm{V}$ & $(\mathrm{Y})$ & \pm & \pm & \pm & & \\
\hline $\mathrm{Cd}^{++}$ & $\mathrm{CdSO}_{4} \cdot{ }^{8} /{ }_{3} \mathrm{H}_{2} \mathrm{O}$ & + & & $(\mathrm{Br})$ & ( $\mathrm{Y})$ & - & & & & \\
\hline $\mathrm{Co}^{++}$ & $\mathrm{CoSO}_{4} \cdot 7 \mathrm{H}_{2} \mathrm{O}$ & $\pm \sim+$ & $(\mathrm{Br})$ & & & - & & & & \\
\hline $\mathrm{Cr}^{+++}$ & $\mathrm{Cr}\left(\mathrm{NO}_{3}\right)_{3} \cdot 9 \mathrm{H}_{2} \mathrm{O}$ & $\pm \sim+$ & $(\mathrm{Br})$ & & & - & & & & \\
\hline $\mathrm{Cu}^{++}$ & $\mathrm{CuSO}_{4} \cdot 5 \mathrm{H}_{2} \mathrm{O}$ & ++ & $(\mathrm{G})$ & $\mathrm{Br}$ & $\mathrm{Y}$ & + & + & \pm & + & B1. V \\
\hline $\mathrm{Fe}^{++}$ & $\mathrm{FeSO}_{4} \cdot 7 \mathrm{H}_{2} \mathrm{O}$ & ++ & G. Br & G. Br & & + & + & + & & Bl. V \\
\hline $\mathrm{Fe}^{+++}$ & $\mathrm{Fe}\left(\mathrm{SO}_{4}\right)_{3}$ & +++ & B. $\mathrm{Br}$ & B. $\mathrm{Br}$ & & + & \pm & 土 & + & Bl. V \\
\hline $\mathrm{Hg}^{++}$ & $\mathrm{HgCl}_{2}$ & +++ & $(\mathrm{G})$ & B. $\mathrm{Br}$ & $\mathrm{Y}$ & ++ & ++ & \pm & & Bl. V \\
\hline $\mathrm{Mo}^{++}$ & $\mathrm{Na}_{2} \mathrm{MoO}_{4} \cdot 2 \mathrm{H}_{2} \mathrm{O}$ & + & $(\mathrm{Br})$ & & $(\mathrm{Y})$ & - & & & & \\
\hline $\mathrm{Pb}^{++}$ & $\begin{array}{l}\mathrm{Pb}\left(\mathrm{CH}_{3} \mathrm{COO}\right)_{2} \cdot \\
3 \mathrm{H}_{2} \mathrm{O}\end{array}$ & + & $(\mathrm{Br})$ & & & - & & & & \\
\hline $\mathrm{Zn}^{++}$ & $\mathrm{ZnSO}_{4} \cdot 7 \mathrm{H}_{2} \mathrm{O}$ & + & & $(\mathrm{Br})$ & & - & & & & \\
\hline $\mathrm{Mg}^{++}$ & $\mathrm{MgSO}_{4} \cdot 7 \mathrm{H}_{2} \mathrm{O}$ & - & & & & - & & & & \\
\hline $\mathrm{Mn}^{++}$ & $\mathrm{MnSO}_{4} \cdot 7 \mathrm{H}_{2} \mathrm{O}$ & - & & & & - & & & & \\
\hline
\end{tabular}

* C: central part, P: periphery, S: surrounding part.

** B: black, Bl: blue, Br: brown, G: grey, V: violet, Y: yellow; ( ) : slightly discolor.

*** From Nippon Noyaku Co.

$$
\begin{gathered}
\text { 第 } 3 \text { 表 フェノール類 }\left(10^{-2} \mathrm{M}\right) \text { による水稲葉上の人工病斑の形成ならびに } \\
\text { その部分に持ける澱粉流転作用の阻止 }
\end{gathered}
$$

Tab. 3. The formation of artificial spots and the inhibition of starch translocation

\begin{tabular}{|c|c|c|c|c|c|}
\hline \multirow{3}{*}{ Phenols } & \multicolumn{4}{|c|}{ Formation of artificial spots } & \multirow{3}{*}{$\begin{array}{c}\text { Inhibition of starch } \\
\text { translocation }\end{array}$} \\
\hline & \multirow{2}{*}{$\begin{array}{l}\text { Degree of } \\
\text { formation }\end{array}$} & \multicolumn{3}{|c|}{ Color of spots } & \\
\hline & & $\mathrm{C}^{*}$ & $\mathrm{P}$ & $\mathrm{S}$ & \\
\hline No dark-treatment & - & & & & - \\
\hline “Rino" **** & - & & & & - \\
\hline Catechol & ++ & $\mathrm{B} * *$ & $\mathrm{~B}$ & & - \\
\hline Resorcine & ++ & $\mathrm{Y} . \mathrm{Br}$ & $\mathrm{Y} . \mathrm{Br}$ & & - \\
\hline Hydroquinon & + & $\mathrm{Br}$ & $\mathrm{Br}$ & $(\mathrm{Y})$ & - \\
\hline Pyrogallol & + & B. $\mathrm{V}$ & B. $\mathrm{V}$ & & - \\
\hline Phloroglucine & - & & & & - \\
\hline$\beta$-Naphthol & $\pm \sim+$ & $* * *$ & & & - \\
\hline
\end{tabular}
therein by various phenol solutions on rice leaves.

* C: central part, P: periphery, S: surrounding part.

** B: black, $\mathrm{Br}$ : brown, $\mathrm{V}$ : violet, $\mathrm{Y}$ : yellow; ( ) : slightly discolor.

*** water-soaked.

**** From Nippon Noyaku Co. 
第 4 表 水稲葉上の人工病斑の形成ならびに澱粉流転作用の阻止力

$$
\text { による種々の化合物の分類 }
$$

Tab. 4. Grouping of various chemicals $\left(10^{-2} \mathrm{M}\right)$ according to their ability

to from artificial spots on rice leaves and to inhibit the starch translocation therein.

\begin{tabular}{|c|c|c|c|c|c|}
\hline Groups & $\begin{array}{l}\text { Formation of } \\
\text { artificial spots }\end{array}$ & $\begin{array}{l}\text { Iodo-starch } \\
\text { reaction }\end{array}$ & Respiratory inhibitors & Metal ions & Phenols \\
\hline $\mathrm{I}$ & + & + & $\begin{array}{l}\text { Monochloroacetic acid* } \\
\text { Monoiodoacetic acid* } \\
\text { Monobromoacetic acid* }\end{array}$ & $\begin{array}{l}\mathrm{Ag}^{+} \\
\mathrm{Cu}^{++} \\
\mathrm{Fe}^{++} \\
\mathrm{Fe}^{+++} \\
\mathrm{Hg}^{++}\end{array}$ & \\
\hline \multirow[t]{2}{*}{$\Pi$} & $\begin{array}{l}+ \\
+\end{array}$ & - & $\begin{array}{l}\text { o-phenanthroline } \\
\text { K-ethylxanthate } \\
\text { Na-diethyldithiocarbamate } \\
2,4 \text {-dinitrophenol** }\end{array}$ & $\begin{array}{l}\mathrm{Ca}^{++} \\
\mathrm{Mo}^{++} \\
\mathrm{Pb}^{++} \\
\mathrm{Zn}^{++}\end{array}$ & $\begin{array}{l}\text { Catechol } \\
\text { Resorcine } \\
\text { Hydroquinon } \\
\text { Pyrogallol }\end{array}$ \\
\hline & $\pm \sim+$ & - & & $\begin{array}{l}\mathrm{Co}^{++} \\
\mathrm{Cr}^{+++}\end{array}$ & $\beta$-Naphthol \\
\hline III & - & - & $\begin{array}{l}\text { Phloridzin } \\
\mathrm{NaF} \\
\mathrm{NaN}_{3} \\
\boldsymbol{\alpha}, \boldsymbol{\alpha}^{\prime} \text {-dipyridyl } \\
\text { 8-Hydroxyquinoline } \\
\text { Salicylaldoxime } \\
\mathrm{KCN}^{* * *}\end{array}$ & $\begin{array}{l}\mathrm{Mg}^{++} \\
\mathrm{Mn}^{++}\end{array}$ & Phloroglucine \\
\hline $\begin{array}{r}* \\
* * \\
* * *\end{array}$ & $\begin{array}{l}10^{-3} \mathrm{M} \\
-4 \mathrm{M} \\
10^{-2} \mathrm{M}\end{array}$ & & & & \\
\hline
\end{tabular}

第 5 表 水稲葉の $\beta$-amylase 活性に対する第 1 群化合物の直接的な阻害作用

Tab. 5. The direct inhibition of various chemicals in Group I to the activity of $\beta$-amylase in rice leaves.

\begin{tabular}{|c|c|c|c|c|}
\hline \multirow{2}{*}{ Chemicals } & \multirow{2}{*}{ Final conc. (M) } & \multicolumn{2}{|c|}{ Activity of $\beta$-amylase } & \multirow{2}{*}{ Inhibition $(\%)$} \\
\hline & & Abs. * & Relative & \\
\hline Control (DW) & - & 0.385 & 100 & - \\
\hline Monochloroacetic acid & $2 \times 10^{-3}$ & 0.260 & 68 & 32 \\
\hline Monoiodoacetic acid & $"$ & 0.140 & 38 & 62 \\
\hline Monobromoacetic acid & " & 0.450 & 116 & -16 \\
\hline $\mathrm{Ag}^{+}$ & $"$ & 0.155 & 40 & 60 \\
\hline $\mathrm{Cu}^{++}$ & " & 0.000 & 0 & 100 \\
\hline $\mathrm{Fe}^{++}$ & " & 0.490 & 127 & -27 \\
\hline $\mathrm{Fe}^{+++}$ & " & 0.000 & 0 & 100 \\
\hline $\mathrm{Hg}^{++}$ & $"$ & 0.000 & 0 & 100 \\
\hline
\end{tabular}

* The activity was expressed by $m g$ of reducing sugar formed in $5 \mathrm{hr}$. per $40 \mathrm{mg}$ of fresh tissue at $37^{\circ} \mathrm{C}, \mathrm{pH} 6.0$. 
第 6 表 水稲葉の $\boldsymbol{\beta}$-amylase 活性に対する第 2 群化合物の直接的な阻害作用

Tab. 6. The direct inhibition of various chemicals in Group $\Pi$ to the activity of $\beta$-amylase in rice leaves.

\begin{tabular}{|c|c|c|c|c|}
\hline \multirow{2}{*}{ Chemicals } & \multirow{2}{*}{$\begin{array}{l}\text { Final conc. } \\
\text { (M) }\end{array}$} & \multicolumn{2}{|c|}{ Activity of $\beta$-amylase } & \multirow{2}{*}{ Inhibition $(\%)$} \\
\hline & & Abs. * & Relative & \\
\hline Control (DW) & - & 0.385 & 100 & - \\
\hline 2.4-dinitrophenol & $2 \times 10^{-5}$ & 0.770 & 200 & -100 \\
\hline $\mathrm{Zn}^{++}$ & $2 \times 10^{-3}$ & 0.200 & 52 & 48 \\
\hline Control (DW) & - & 0.240 & 100 & - \\
\hline K-ethylxanthate & $2 \times 10^{-3}$ & 0.265 & 110 & -10 \\
\hline Na-diethyldithiocarbamate & " & 0.170 & 71 & 29 \\
\hline $\mathrm{Cd}^{++}$ & $"$ & 0.095 & 40 & 60 \\
\hline $\mathrm{Pb}^{++}$ & " & 0.085 & 35 & 65 \\
\hline Catechol & $"$ & 0.340 & 142 & -42 \\
\hline Pyrogallol & $"$ & 0.325 & 135 & -35 \\
\hline
\end{tabular}

* See Tab. 5 .

第 7 表 水稲葉の $\beta$-amylase 活性に対する $\mathrm{HgCl}_{2}$ 溶液 $(0.01 \mathrm{M}$ ) の間接的な阻害作用

Tab. 7. The indirect inhibition of $\mathrm{HgCl}_{2}$ solution $\left(10^{-2} \mathrm{M}\right)$ to the activity of $\beta$-amylase in rice leaves.

\begin{tabular}{|c|c|c|c|c|}
\hline \multirow{2}{*}{ No. of experiment } & \multirow{2}{*}{ Hours in dippiing } & \multicolumn{2}{|c|}{ Activity of $\beta$-amylase* } & \multirow{2}{*}{ Relative value } \\
\hline & & Control (DW) & $\mathrm{HgCl}_{2}$ & \\
\hline \multirow{4}{*}{$\mathrm{I}$} & 0 & 0.505 & 0.505 & 100 \\
\hline & 1 & 0.340 & 4.730 & 1399 \\
\hline & 3 & 2.125 & 0.060 & 3 \\
\hline & 5 & 0.470 & 0.000 & 0 \\
\hline \multirow{4}{*}{$\Pi$} & 0 & 0.365 & 0.365 & 100 \\
\hline & 2 & 0.920 & 2.535 & 275 \\
\hline & 4 & 0.455 & 0.000 & 0 \\
\hline & 6 & 0.380 & 0.000 & 0 \\
\hline
\end{tabular}

* See Tab. 5 .

しない）がみられた。一方人工病斑を形成しないもの はすべてョード澱粉反応を呈しないので，澱粉流転作 用を阻止しないものと考えられる。以上の観察結果か ら,これらの数多くの物質を（1）人工病斑を形成し かつ澱粉流転作用を阻止するもの（第 1 群），（2）人 工病玟を形成するが澱粉流転作用を阻止しないもの,

(第 2 群) および (3)人工病玟を形成せず, したがつ て澱粉流転作用を阻止しないもの（第 3 群）の 3 群に 分けることができる（第 4 表）。

\section{II. 種々の化合物による澱粉分解作用の抑制}

1. 水稻葉の $\beta$-amylase 活性に対する種々の化合 物の直接的な阻害作用 以上の実験結果からある種の 物質を水稻葉上に滴下寸ると，その部分に拈いて澱粉
流転作用が阻止されることが明らかになつたが，この 原因がこれらの物質による水稻葉の $\beta$-amylase に対 する直接的な阻害作用によるのか否かを調べるため, 前記の第 1 および 2 群に属する数種の物質を添加して $\beta$-amylase の阻害実験を行なつた(第 5 および 6 表)。 ただし第 3 群に属するものは澱粉流転作用を阻止しな いので以後の実験には供試しなかつた。第 1 群に属す るもののうち monobromoacetic acid および $\mathrm{Fe}^{++}$ の添加では $\beta$-amylase の活性は阻書されなかつたが monochloroacetic acid, monooidoacetic acid および $\mathrm{Ag}^{+}$ではかなりの阻害を, $\mathrm{Cu}^{++}, \mathrm{Fe}^{++}$および $\mathrm{Hg}^{++}$ などでは完全に阻書された。一力第 2 群に属するもの では, $\mathrm{Cd}^{++}, \mathrm{Pb}^{++}$および $\mathrm{Zn}^{++}$添加がかなりの阻害 
第 8 表 水稲葉の $\beta$-amvlase 活性に対する第 1 群化合物 $\left(10^{-2} \mathrm{M}\right)$ の間接的な阻害作用

Tab. 8. The indirect inhibition of various chemicals in Group I $\left(10^{-2} \mathrm{M}\right)$ to the activity of $\beta$-amylase in rice leaves.

\begin{tabular}{|c|c|c|c|c|c|c|}
\hline \multirow{3}{*}{ Chemicals } & \multicolumn{6}{|c|}{ Hours in dipping } \\
\hline & \multicolumn{2}{|l|}{3.5} & \multicolumn{2}{|c|}{7.0} & \multicolumn{2}{|c|}{24.0} \\
\hline & $\begin{array}{c}\text { Activity* of } \\
\beta \text {-amylase }\end{array}$ & $\begin{array}{c}\text { Relative } \\
\text { value }\end{array}$ & $\begin{array}{c}\text { Activity* of } \\
\beta \text {-amylase }\end{array}$ & $\begin{array}{l}\text { Relative } \\
\text { value }\end{array}$ & $\left|\begin{array}{c}\text { Activity* of } \\
\beta \text {-amylase }\end{array}\right|$ & $\begin{array}{c}\text { Relative } \\
\text { value }\end{array}$ \\
\hline Control (DW) & 0.220 & 100 & 0.230 & 100 & 0.315 & 100 \\
\hline Monochloroacetic acid & 0.085 & 39 & 0.060 & 26 & 0.065 & 21 \\
\hline Monoiodoacetic acid & 1.590 & 723 & 0.835 & 363 & 0.045 & 14 \\
\hline Monobromoacetic acid & 0.690 & 314 & 0.000 & 0 & 0.045 & 14 \\
\hline Control (DW) & - & - & - & - & 0.235 & 100 \\
\hline $\mathrm{Ag}^{+}$ & - & - & - & - & 0.000 & 0 \\
\hline $\mathrm{Cu}^{++}$ & - & - & - & - & 0.020 & 9 \\
\hline $\mathrm{Fe}^{++}$ & - & - & - & - & 0.145 & 62 \\
\hline $\mathrm{Fe}^{+++}$ & - & - & - & - & 0.100 & 43 \\
\hline
\end{tabular}

* See Tab. 5 .

第 9 表 水稲葉の $\beta$-amylafe 活性に対する第 2 群化合物の間接的な阻害作用

Tab. 9. The indirect inhibition of various chemicals in Group II to the activity of $\beta$-amylase in rice leaves.

\begin{tabular}{l|c|c|c}
\hline \multicolumn{1}{c|}{ Chemicals } & $\begin{array}{c}\text { Conc. } \\
(\mathrm{M})\end{array}$ & $\begin{array}{c}24 \text { hours in dipping } \\
\text { Activity* of } \\
\beta \text {-amylase }\end{array}$ & $\begin{array}{c}\text { Relative } \\
\text { value }\end{array}$ \\
\hline Control (DW) & - & 0.315 & 100 \\
2, 4-dinitrophenol & $10^{-4}$ & 0.225 & 71 \\
\hline Control (DW) & - & 0.305 & 100 \\
K-ethylxanthate & $10^{-2}$ & 0.400 & 131 \\
Na-diethyldithiocarbamate & $"$ & 0.585 & 192 \\
Cd $^{++}$ & $"$ & 0.770 & 253 \\
Pb $^{++}$ & $"$ & 0.215 & 71 \\
Catechol & $"$ & 0.390 & 128 \\
\hline Contorl (DW) & - & 0.235 & 100 \\
$\mathrm{Zn}^{++}$ & $10^{-2}$ & 0.325 & 128 \\
\hline
\end{tabular}

* See Tab. 5 .

作用を示したが，2，4-dinitrophenol， catechol およ び pyrogallol のようにフェノール系の物質の添加で は逆に活性はかなり大となるようである。以上の結果 から, 第 1 群に属するものの多〈は水稲葉の $\beta$-amylase を直接阻害したが，第 2 群に属するものには阻害 するものとしないものとがあり， $\beta$-amylase を直接 的に阻害する能力のあるものが必ず澱粉流転作用を阻 止するとは限らないようである。

2. 水稲葉の $\beta$-amylase の活性に対する $\mathbf{H g C l}_{2}$ 溶 液の間接的な阻害作用 以上の結果から化合物滴下
による水稻葉の 澱粉流転作用阻止は $\beta$ amylase の直接的な阻害のほかに，他の 酵素を阻害した結果間接的におこる $\boldsymbol{\beta}$ amylase の活性低下も考元られる。こ のことは化合物の溶液に一定時間浸漬した 水稻葉片から調製した粗酵素液について B-amylase の活性を測定することによつ てある程度調べることができる。まず初め にこれらの物質の水稻葉内への透と浸漬 時間との関係を知るため水稲葉片を $\mathrm{HgCl}_{2}$ 溶液に種々の時間浸漬して, $\beta$-amylase $の$ 活性を測定した(第 7 表)。 $10^{-2} \mathrm{M} \mathrm{HgCl}_{2}$ 溶 液に浸漬した場合には 2 時間以内まででは B-amylase の活性はむしろ大であつたが， 3 時間以上の浸漬ではほとんど 0 に等しく なり，完全に阻害されたと考えられた。

\section{3. 水稲葉の $\beta$-amylase の活性に対す} る種々の化合物の間接的な阻害作用 前記 第 1 および 2 群に属する物質の溶液に, $\mathrm{HgCl}_{2}$ の場合と同様，水稲葉を浸漬し，一定時間後に 取出して調製した粗酵素液について $\beta$-amylase の活 性を測定した（第 8 执よび 9 表）。24 時間浸漬した場 合の結果から,第 1 群に属する物質では,すべてがかな り強く $\beta$-amylase の活性を阻害したが，第 2 群に属 するものでは大部分が阻害作用をもたず，かえつてか なり活性を高めるものも認められた。 


\section{考察}

水稲ごま葉枯病々斑周縁組織では $\beta$-amylase の活 性が低下寸ることから，澱粉分解作用の抑制がその部 分における多量の澱粉の蓄積される原因の一部であろ 万と考えてきたが，さらに測粉分解作用が抑制される 原因として，これに関与する酵素（直接的には phosphorylase や amylase 群であるが, 間接的には解糖 系や酸化系などの呼吸に関与する酵素群をる含める) が阻害されているのではないかと考えた。るしそ5で あれば, この阻害物質はもちろん侵入した病原菌自身 の, あるいは異常を起こした水稲葉の代謝産物として 本病々斑周縁組織で生産されるものと推定されるので あるが，これらの物質を同定することはひじょうに困 難である。そこで既知の澱粉分解に関与寸る酵素の阻 害㓮を人工的に水稲葉組織に与えることによつて，そ の場で澱粉の蓄積を起こさせらるならば，ある程度病 原菌あるいは寄主組織によつて生産される代謝産物の 万ち，搌粉の異常蓄積を引き起こすと思われる物質を 想像することできるであろう。本実験はこのよ5な立 場に立つて, 澱分解作用を抑制する物質を傍証的意味 に执いて推定するために種々の化合物を水稻葉上に滴 下して人工病斑を形成させ，澱粉分解作用を抑制しう るか否かを調べたものである。

まず初めにこれらの化合物の澱粉の分解之移行とい ラ二つの面を考慮に入れた激粉流転作用に対する影響
を調べた結果は，第 4 表に示したよ5に，ある種の化 合物は明らかに㱖粉流転作用を阻止することを認め た。しかしこのようにして形成させた人工病斑では, これらの化合物の滴下部は大部分褐色壊死を起こした ので，技そらくその部分の細胞は死んでいるものと思 われる。しかし澱粉分解作用は細胞の死とは一応別個 に考慮してよいと思われる（細胞が死んでいても激粉 分解作用が抑制されない場合がある一一第 2 群に属す る化合物を滴下した場合）ので，ここでは切り離して 考えたい。したがつてこれらの化合物の澱粉流転作用 の阻止力と分解作用としての水稲葉の $\beta$-amylase $に$ 対する直接的あるいは間接的な阻害力との関係を調べ たが，それらをわかりやすく図示すれば第 3 図のよ5 である。この四からわかるように，澱粉流転作用を阻 止する物質の大部分が直接 $\boldsymbol{\beta}$-amylase を阻害し, 少な くとも間接的にはすべての物質が程度の差はあるが一 応阻害する。特に monoiodoacetic acid, $\mathrm{Ag}^{+}, \mathrm{Cu}^{++}$, $\mathrm{Fe}^{+++}$および $\mathrm{Hg}^{++}$などは直接的にも間接的にもか なり強く阻害する。これらの物質はすべて SH-阻害剤 であつて, $\beta$-amylase が SH-酵素であることから考 えて，このことは当然である。これに対して澱粉流転 作用を阻害しない物質のなかにも $\beta$-amylase を直接 的に阻害するものがあるが，間接的に阻害するものは 比較的少なく，たとえ阻害する場合ですとの程度は小 であり，むしろ逆にかなり活性を高めるものがある。 この第 2 群に属する物質の中には, SH-阻害剤は例外

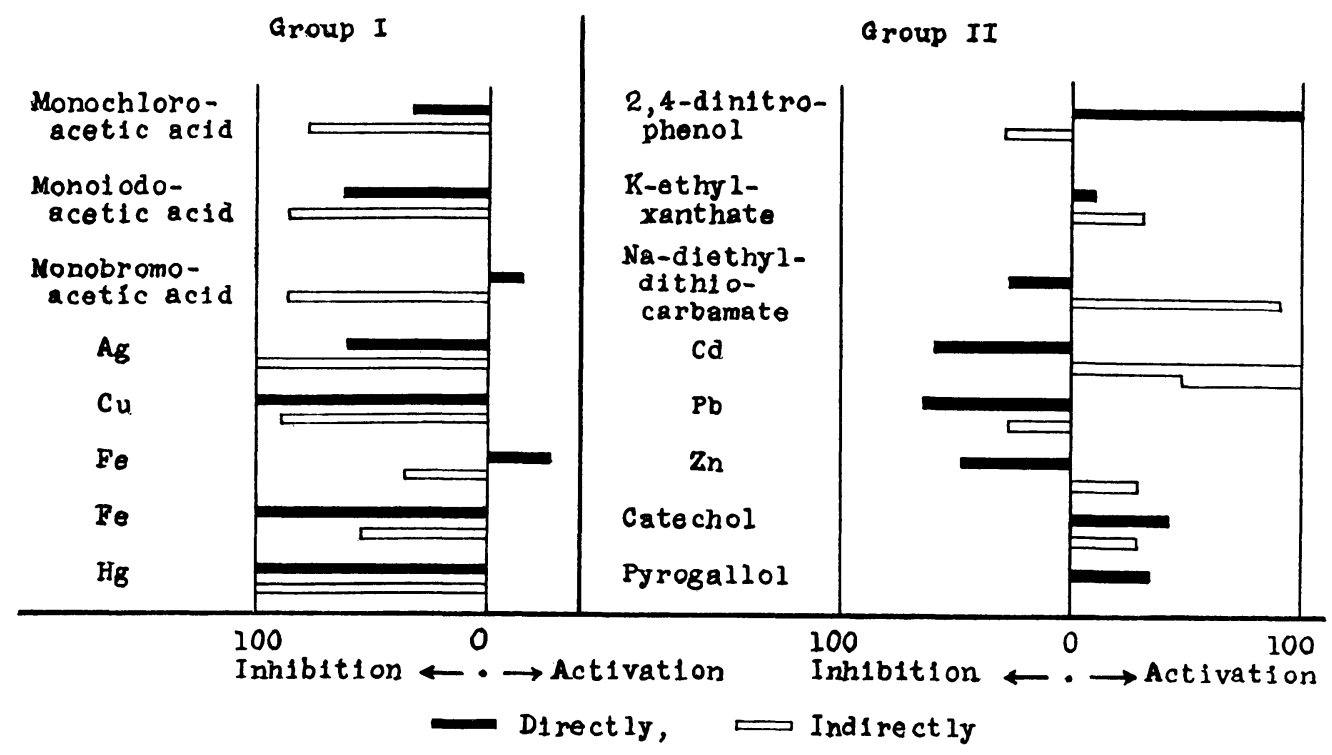

第 3 図水稲葉の $\beta$-amylase 活性に対する種々の化合物の阻害作用

Fig. 3 The inhibition of various chemicals to the activity of $\beta$-amylase in rice leaves. 
的に存在する程度で, 大部分は SH-阻害剤ではない。

以上の実験結果から，本病々班周縁組織に打ける澱 粉分解作用の抑制には, SH-阻害剤の上らな物質の存 在か深い関係をもつものと考えられるが，このような 物質が水稻あるいは病原菌によつて生産されるとして も，寄主と寄生菌の共存の場においてはたしてそのど ちらに由来して生ずるか，現在までのところ報告され たものがない。水稲に本病々原菌を接種し，20２4時 間後に観察すると, 病斑はごく小さい点状の初期の段 階を示し，その周縁部では澱粉はかえつて消失する1)。 したがつてたとえ阻害物質が水稲自身に由来すると仮 定しても, 感染以前にすでに阻害に十分な濃度に存在 するとは考学難く，むしろ病原菌の侵入に伴なつて おこる異常代謝の結果生成されたものと考えるのが 妥当のよ5である。一方ごま葉枯病菌の培養汇液が $\beta$-amylase の活性を阻害することは後藤 ${ }^{2}$ が認めてお り, 筆者らる予備実験的に認めている。したがつて SH-阻害剤のような物質が本菌の代謝産物として培養 汇液中に生産されることも考えられる。この点につい ては現在実験を進めている。

また涉粉が蓄積するごま葉枯病々斑周縁組織では, 細胞は生きていて外観上何ら異常が認められないが, 本実験で形成させた人工病斑では壊死部に搌粉が残留 する。この点が前述したように両病斑に打ける澱粉異 常分布の最も大きな違いである。第 1 表にも示したよ 5に, monobromoacetic acid 滴下に上る人工病斑の 周縁部は黄変の程度は小であつて，括そらく生きてい るものと思われ，この部分には澱粉が残留している。 このような状態を人工的に作りだすことに成功すれ ば, 自然病斑と対比して考えるのに最も好都合である。 この点に関して上記第 1 群の化合物やさらに本実験に は使用しなからた化合物についても, より低濃度で供 試してモデル実験を繰返して行きたいと考えている。
摘

水稲ごま葉枯病々斑周縁組織では $\beta$-amylase の活 性が低下するが，この原因を追及するために，呼吸系 酵素阻害凨，金属塩類およびフェノール類などの溶液 を暗処理中の水稻葉上に滴下して，人工病斑の形成な らびに澱粉流転作用の阻止力などを調べた。その結果 これらの物質を，(1）人工病斑を形成し，から澱粉流 転作用を阻止するもの (第 1 群)，（2）人工病斑を形 成するが激粉流転作用を阻止しないもの（第 2 群）お よび（3）人工病斑を形成せず，したがつて澱粉流転 作用を阻止しないもの（第 3 群）に分けた。

一方水稻葉から調製した粗酵素液にこれらの物質を 添加して，あるいはこれらの物質に水稻葉を浸漬した 後調製した粗酵素液について $\beta$-amylase の活性を測 定し,これらの物質の $\beta$-amylase 亿対する直接ある いは間接的な阻害力を調べた。第 1 群に属する物質は すべて阻害作用を示したが，第 2 群に属する物質は示 さないものが多かつた。これらのことから，本病々斑 周縁組織では $\beta$-amylase を阻害寸る物質が，水稲自 身あるいは侵入した病原菌によつて生産されているる のと考えた。

(1960 年 5 月 23 日受理)

\section{引用 交 献}

1）赤井重恭，田中筧康，野口喜久子（1958）：日植病 報, $23(3): 111 \sim 116$.

2) 後藤岩三郎 (1958)：山形大学紀要（農学), $2(4)$ : 1 152.

3) James, W. O. (1953):Plant Respiration. Oxford pp. $218 \sim 219$.

4) 京大農芸化学教室編（1957）：農芸化学実験書, 東 京, p. 619.

5）田中寛康，赤井重恭（1960）：日植病報，25（2） : 80-84.

\section{Summary}

The writers have previously reported a decrease of $\beta$-amylase activity in rice leaf tissues surrounding the spots which occured after the inoculation with conidia of Cochliobolus miyabeanus. To clarify the cause of this phenomenon, we have investigated the formation of artificial spots by placing a drop of each solution of such chemicals as respiratory inhibitors, metal salts and phenols, on leaves of rice plants placed in the dark, and the influence of such chemicals on the decomposition of starch present in artificial spots and their surrounding tissues. In view of our exprimental results, these chemicals were divided into three groups as follows: (1) chemicals which form artificial spots and inhibit the starch translocation in rice leaves (Group I), (2) those which form artificial spots, but not inhibit the starch translocation (Group II) and (3) those which have ability neither to form artificial spots nor to inhibit the starch translocation (Group III). We have also investigated the direct or indirect inhibition, by the above-mentioned chemicals, of the activity of $\beta$-amylase prepared from rice leaves. All the chemicals belonging to Group I strongly inhibited the activity of this enzyme, whereas most of the chemicals belonging to Group II did not inhidit it. From the results of these experiments, it seems that a substance or substances which inhibit the activity of $\beta$-amylase may be produced by the tissues surrounding the spots on rice leaves or by the causal fungus itself. (Laboratory of Phytopathology, Faculty of Agriculture, Kyoto University). 